\title{
Angiotensin Converting Enzyme Inhibition Decreases Cell Turnover in the Neonatal Rat Heart
}

\author{
JEONG HOON CHOI, KEE HWAN YOO, HAE WON CHEON, KYUNG BURM KIM, YOUNG SOOK HONG, \\ JOO WON LEE, SOON KYUM KIM, AND CHUL HWAN KIM
}

Department of Pediatrics [J.H.C., K.H.Y., H.W.C., K.B.K., Y.S.H., J.W.L., S.K.K.] and Department of

Pathology [C.H.K.], Korea University, Seoul, Korea

\begin{abstract}
The renin angiotensin system plays an important role in
growth and development. Exposure of the neonate to an ACE
inhibitor increases mortality and results in growth retardation and
abnormal development. We have demonstrated that ACE inhibi-
tion in the developing kidney increases apoptosis and decreases
cell proliferation, which may account for renal growth impair-
ment. To evaluate the role of endogenous angiotensin in cardiac
development, the relationship between ACE inhibition, cell pro-
liferation, apoptosis, several modulators of apoptosis (bcl-2,
bcl-xl, and clusterin) was examined in the developing rat heart.
Thirty-five newborn rat pups were treated with enalapril (30
mg/kg/d) or a vehicle (control group) for $7 \mathrm{~d}$, and hearts were
removed for rt-PCR and Western blotting of bcl-2, bcl-xl, and
clusterin. An additional 10 rat pups were treated with hydralazine
(10 mg/kg/d) or a vehicle, to serve as a hypotensive control. Cell
proliferation was determined by PCNA immunostaining, and
apoptosis was detected using the total TUNEL technique. Ena-
lapril treatment resulted in a $24 \%$ mortality, reduced body
weight, and decreased heart weight $(p<0.05)$. Enalapril de-
creased proliferating myocytes by $23 \%$, and reduced proliferat-
ing cardiac interstitial cells by $8.1 \%(p<0.05)$. Enalapril also
\end{abstract}
The renin angiotensin system (RAS) plays a role in the maintenance of systemic arterial pressure in the newborn, and provides a homeostatic response to hypovolemia (1). Davidson (1) demonstrated parallel increases in plasma renin activity in arterial ANG-II concentration occurred in the immediate minutes after delivery. Furthermore, the release of catecholamines may be stimulated by the production of ANG II, and the activation

Received October 26, 1999; accepted April 27, 2001.

Correspondence: Kee Hwan Yoo, Ph.D., Department of Pediatrics, Korea University Guro Hospital, 80 Guro-dong, Guro-gu, Seoul, Korea; e-mail: guroped@korea.ac.kr

This study was supported in part by White Mountain research grant. The authors are grateful to Dr. Chevalier (University of Virginia) for his helpful advice on this manuscript.

DOI: 10.1203/01.PDR.0000025654.32501.3D decreased myocytes apoptosis by $60 \%$, but the proportion of myocytes undergoing apoptosis was 10-fold less than that of proliferating cells. Cardiac bcl-2 mRNA, clusterin mRNA, bcl-2 protein, and bcl-xl protein content were not changed, but clusterin protein expression was decreased by enalapril treatment. Hydralazine did not alter cardiac cell proliferation or apoptosis. We conclude that ACE inhibition decreases cell turnover in the developing rat heart, which may contribute to cardiac growth impairment. The loss of myocytes may lead to greater myocyte hypertrophy and myocardial damage during later life. (Pediatr Res 52: 325-332, 2002)

$\quad$ Abbreviations
ACE, angiotensin converting enzyme
ANG II, angiotensin II
GAPDH, glyceraldehyde, 3-phosphate dehydrogenase
rt-PCR, reverse, transcriptase PCR
TUNEL, Terminal deoxynucleotidyl transferase mediated
dUTP nick end labeling
PCNA, proliferating cell nuclear antigen
RAS, renin, angiotensin system

of the sympathoadrenal system at birth has been implicated in several adaptive processes and structural integrity (2).

In newborn animals and human infants, the activity of the RAS increases at birth, which is important in regulating cellular growth and organ differentiation $(1,3)$. ANG-II, which is a final product of the RAS, has been reported to exert atrophic effect on cardiac myocytes in cultures (4) and in vivo (5). ANG-II may stimulate a growth response in cardiac tissue indirectly, by increased blood pressure and total peripheral vascular resistance, which develops in response to ANG-II receptor coupling in the vasculature (5). Alternatively, ANG-II may have a direct effect by coupling to its cardiac membrane receptor, resulting in the inhibition of protein synthesis in 
cardiac cells by unknown mechanisms (5). A direct role for ANG-II in normal cardiac and vascular growth and abnormal cardiovascular growth observed in primary hypertension is supported by the discovery of an intrinsic cardiac RAS within the blood vessel wall. As shown previously, octapeptide ANG-II directly stimulated protein synthesis and cell growth in embryotic chick myocytes in cell culture (4). The actions of ANG-II in the late suckling period may be a critical determinant of long-term cardiovascular functions in animals (6). Treatment with the ACE inhibitor has cardioprotective effects in animal models with regional myocardial ischemia and has been used effectively in the treatment of congestive heart failure, cardiac hypertrophy, coronary atherosclerosis, myocardial infarction, and postinfarction remodeling (7-10).

Growth and development of individual organs are the result of a balance between cellular proliferation and cell death. However, the significance of cell death has been relatively ignored, and only a few studies have directed attention to the cardiovascular system. Apoptosis, or programmed cell death, is essential for normal development, and dysregulation of the process can lead to a spectrum of defects ranging from embryonic lethality to tissue specific pertrovation of postnatal development. In addition to its well-documented effects on cellular proliferation and hypertrophy, ANG-II is also now recognized to modulate apoptosis (11). The oncoproteins, bcl-2 and bcl-x, initially discovered in b-cell lymphoma, have been reported to play a role in the prevention of apoptosis. The bcl-2 protooncogene is a regulatory protein molecule related to apoptosis, and has been shown to suppress apoptosis in a number of model systems (12). Clusterin is another apoptosis related molecule whose precise physiologic or pathologic role remains poorly defined. Clusterin appears to play a major role in promoting epithelial cell aggregation and in preventing apoptosis (13). Clusterin has also been shown to play important roles not only in remodeling damaged tissues, but also in tissue reorganization during embryonic development $(14,15)$.

The cellular mechanism underlying angiotensin dependent stimulation of cardiac development in apoptosis in vivo has not yet been elucidated. The present study was therefore designed to investigate the role of endogenous ANG-II in the cellular proliferation and apoptosis of the neonatal rat heart. The experiment and approach consisted of inhibition of endogenous ANG-II production by chronic administration of Enalapril, an $\mathrm{ACE}$ inhibitor, to neonatal rat pups. In addition, the consequences of ACE inhibition on known modulators of apoptosis (bcl-2, bcl-x, and clusterin) were investigated.

\section{METHODS}

Animal preparation. Forty five neonatal rat pups from five pregnant Sprague Dawley rats were breastfed by their own mother throughout the study. Body weights were measured daily from birth and a dose of $30 \mathrm{mg} / \mathrm{kg}$ of enalapril (Sigma Chemical Co., St. Louis, U.S.A.) (E group) and water (control group) were fed via an orogastric tube. A dose of $30 \mathrm{mg} / \mathrm{kg}$ of enalapril is known to block the effects on angiotensin I (16). After $7 \mathrm{~d}$ their hearts were harvested and RNA analysis, protein assays, detection of apoptosis and immune histochemistry were performed. The experimental protocol was approved by the Animal Care Committee of Korea University Guro Hospital.

Effect of hydralazine in newborn rats. According to the methods of Tufro-McReddie (17), Sprague Dawley pups were given hydralazine $(n=5)$ at a s.c. dose of $10 \mathrm{mg} / \mathrm{kg}$ daily from birth to $7 \mathrm{~d}$ of age, and compared with control littermates receiving saline $(n=5)$. This dose of hydralazine has been shown to reduce blood pressure significantly $(18,19)$. At the end of the study period, rats were killed, kidneys were harvested, and PCNA - positive and apoptotic cells were identified as described below.

Immune histochemical stain. To assess cell proliferation, an immune histochemical stain for proliferating cell nuclear antigen (PCNA) was carried out. Harvested hearts were treated in $10 \%$ formalin or Bouin solution (Sigma Chemical Co., St. Louis, U.S.A.) and embedded in paraffin. PCNA-positive cells were detected using the avidin-biotin immunoperoxidase method (Vectastain ABC kit, Burlingame, CA, U.S.A.). Primary antibodies were monoclonal anti-mouse PCNA antibody (1:100 dilution, DAKO, Glostrup, Denmark) in the study group and PBS (PBS) in the negative control group. Each slide was cross-stained with $0.5 \%$ methyl green solution (Trevigen, Gaithersburg, MD, U.S.A.). After dehydration, we compared the slides using a light microscope. PCNA positive cells were measured by counting 20 areas $(25 \times 25 \mu \mathrm{m})$ and the average was statistically obtained. In addition to this, microscopic identification $(400 \times)$ of myocytes and interstitial cells expressing PCNA was performed by two pathologists using a doubleblind method. Cells were counted as myocytes if they showed central ovoid nuclei with clear zone and eosinophilic abundant cytoplasms. Cells with spindle-shaped nuclei and elongated modest cytoplasms were counted as interstitial cells. Count was done randomly throughout all the observed fields.

Detection of apoptosis. Apoptotic nuclei were labeled using the TACS TM 2 TdT In situ Apoptosis Detection Kit (Trevigen, Gaithersburg, MD, U. S. A.). Tissues were fixed in $4 \%$ neutral buffered formalin for $4 \mathrm{~h}$ at $4^{\circ} \mathrm{C}$, dehydrated in graded alcohols, and embedded in paraffin. The samples were then cut into $7 \mu \mathrm{m}$ sections and dried onto silanized slides (Sigma Chemical Co., St. Louis, MO, U.S.A.). Slides were deparaffinized and digested for $10 \mathrm{~min}$ with proteinase $\mathrm{K}(20 \mu \mathrm{g} / \mathrm{ml})$ and an endogenous peroxidase activity was quenched in $2 \%$ hydrogen peroxide for $5 \mathrm{~min}$. Samples were equilibrated using a provided buffer for $2 \mathrm{~min}$ and labeled with biotin dNTP mixtures, TdT, $\mathrm{CoCl}_{2}$, and a labeling buffer according to the manufacturer's advice. Samples were placed inside a humidity chamber in a $37^{\circ} \mathrm{C}$ incubator for $60 \mathrm{~min}$. Negative controls were treated with water instead of TdT. The labeling reaction was stopped using the provided stop buffer for $5 \mathrm{~min}$. Samples were rinsed in PBS for 2 min and treated with the provided Streptavidin-Horseradish Peroxidase Detection solution for 10 min and finally washed 2 times in PBS for 2 min each wash. The color was developed using $0.05 \%$ DAB and $0.05 \%$ hydrogen peroxidase in PBS for $5 \mathrm{~min}$. The sections were rinsed in water and counter-stained in methyl green for $5 \mathrm{~min}$, and the samples were dehydrated and mounted. After dehydration, we compared them using a light microscope. Positive apoptotic cells were measured by counting 20 areas $(25 \times 25 \mu \mathrm{m})$ and 
the average was statistically obtained. In addition to this, microscopic identification $(400 \times)$ of myocytes and interstitial cells stained positively in the TUNEL assay was performed as the same method of PCNA staining. Only morphologically distinct nuclei stained positively by the TUNEL assay were counted as apoptotic. Scattered or clustered apoptotic bodies were not counted as apoptotic due to the lack of identification of cell type.

Isolation of RNA and Analysis of $m R N A$. After being removed, the cardiac tissue was frozen in liquid nitrogen and stored at $-70^{\circ} \mathrm{C}$. Total cellular RNA was isolated using TRIREAGENT (Molecular Research Center, Cincinnati, USA) and homogenized with tissue tearor (Model 985-370, Biospec products, Bartlesville, OK, U.S.A.). 37\% chloroform (200 $\mu \mathrm{L} / 1 \mathrm{~mL}$ TRI reagent) was added to the homogenates and centrifuged at $12,000 \mathrm{rpm}$ for $15 \mathrm{~min}$ in $4^{\circ} \mathrm{C}$ separating into three layers: RNA, DNA, and protein material. The colorless clear upper layer was moved into another Eppendorf tube and isopropanol was added. This was left at room temperature for $15 \mathrm{~min}$ and was then centrifuged at $12,000 \mathrm{rpm}$ for $10 \mathrm{~min}$ in $4^{\circ} \mathrm{C}$ until the white-colored cellular RNA pellet was isolated. It was dried at room temperature for 5 min after washing in $75 \%$ ethanol and was dissolved in $25 \mu \mathrm{L}$ Forma zol (Molecular Research Center, Cincinnati, U.S.A.) at $55^{\circ} \mathrm{C}$ heating block for $10 \mathrm{~min}$ and then stored at $-70^{\circ} \mathrm{C}$. The RNA was quantified spectrophotometrically by absorbance at $260 \mathrm{~nm}$.

cDNA synthesis by reverse transcription (RT) and PCR (PCR). Oligo dT primed 1st strand cDNA was synthesized from the template RNA $1 \mu \mathrm{g}$ through a cDNA Synthesis Kit (Boehringer Mannheim Corp., Indianapolis, IN, U.S.A.). AMV reverse transcriptase was used for synthesis of first strand cDNA for use in subsequent amplification reactions. In the following PCR reaction with the forward primer 5'AATGCATCCTGCACCACCAA-3', the reverse primer 5'GTAGCCATATTCATTGTCATA-3' for GAPDH designed from DNA template of rats, 5'-CGGGTACCGACAAT-
A
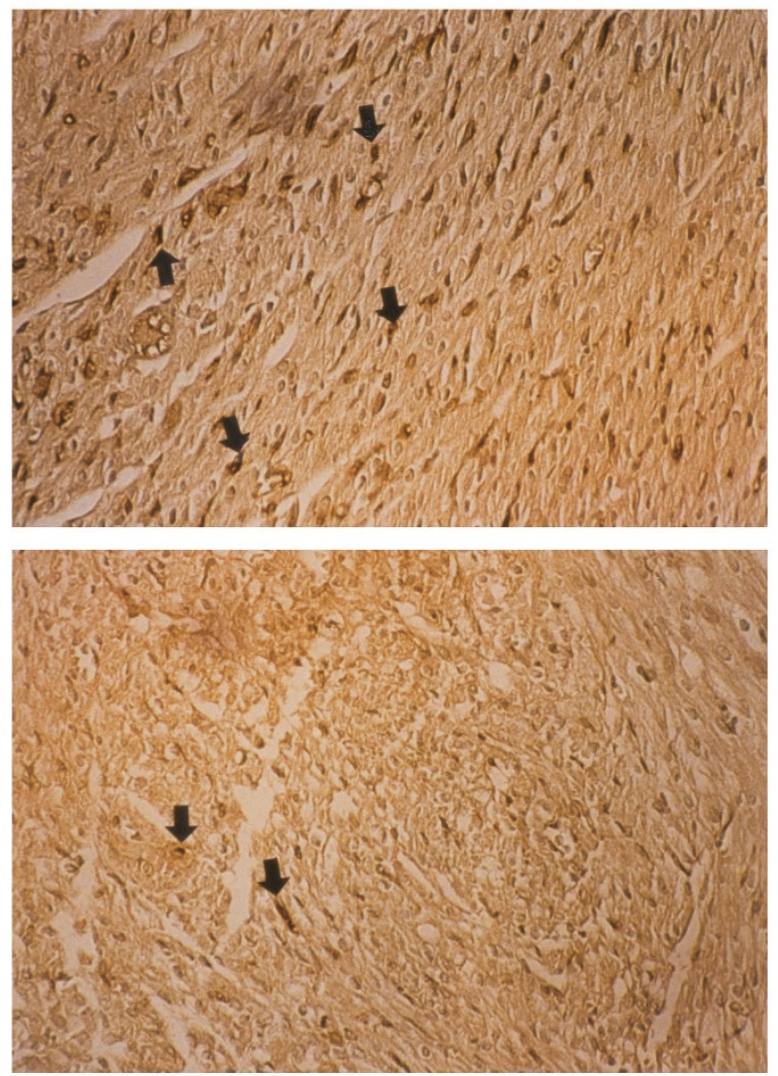

B

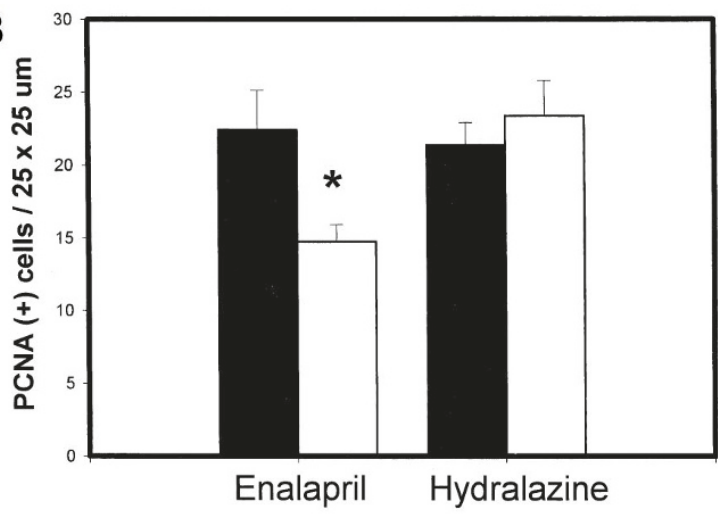

C

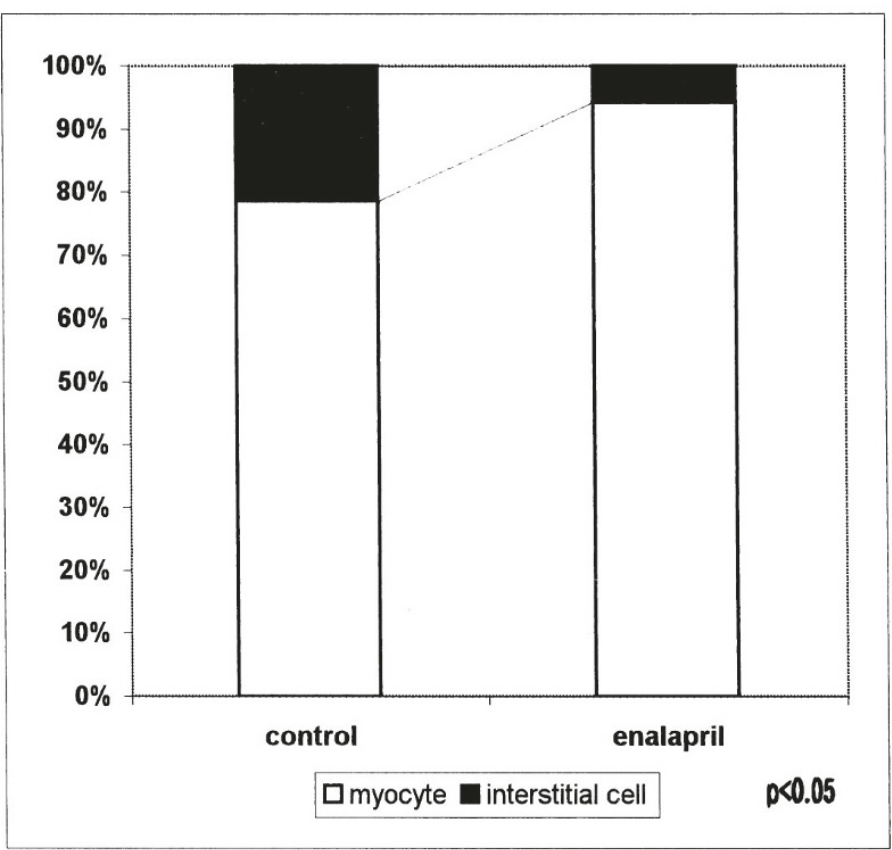

Figure 1. PCNA positive proliferating cells in the heart. $(A)$ Immune- histochemical stain for PCNA in both groups shows that proliferating cells in the E group is decreased more than the control group. Black arrows: PCNA positive proliferating cell ( $\times 400$, top: control, bottom: E group). (B) Number of PCNA positive cells measured by counting 20 areas, $25 \times 25 \mu \mathrm{m}, p<0.05$ (black bar: control, white bar: enalapril or hydralazine treated group). (C) Percentage of PCNA positive myocytes and interstitial cells between control and enalapril treated group, $p<0.05$. 

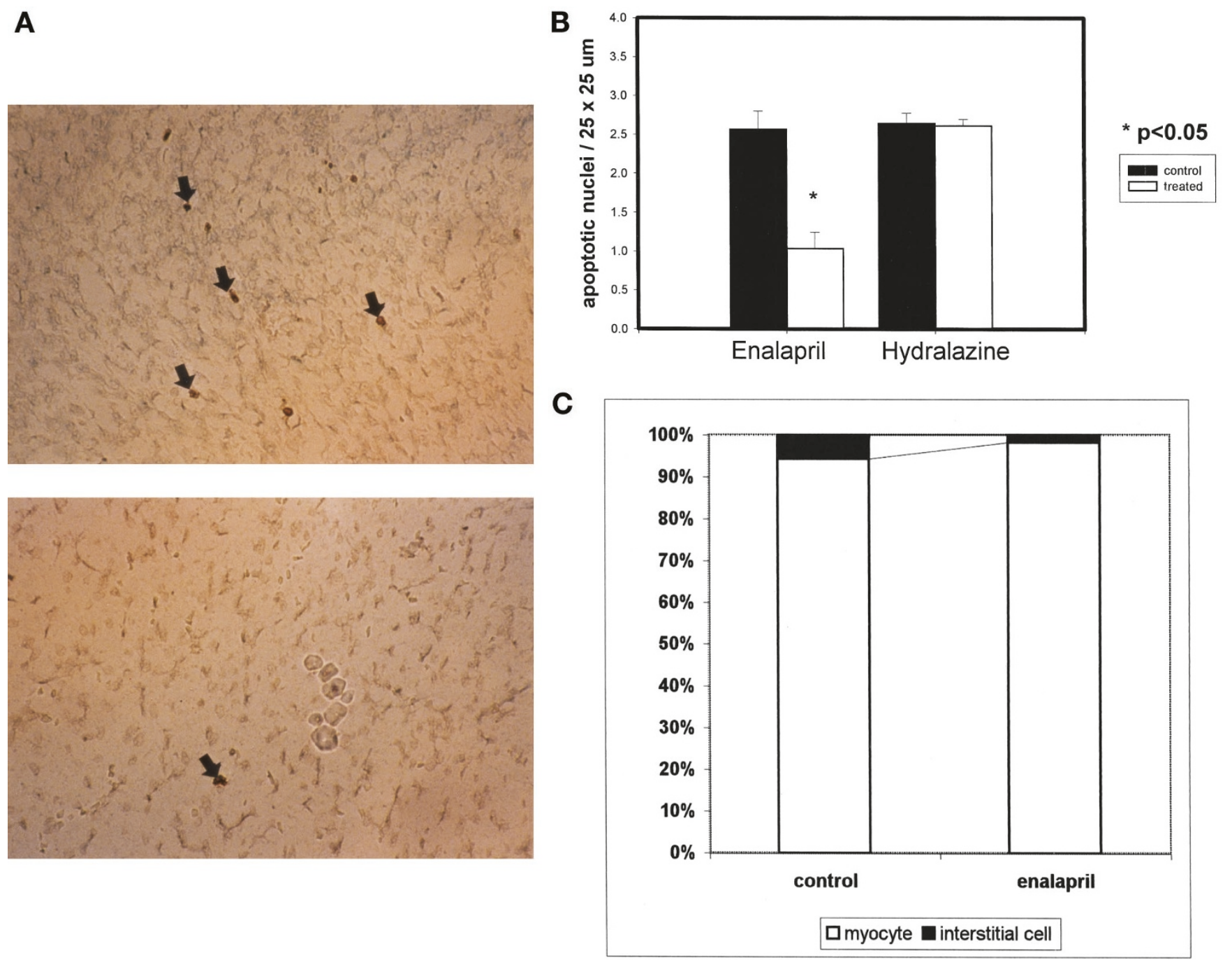

Figure 2. Distribution of apoptosis in the myocardium of both group. $(A)$ The distribution of apoptotic cells in the myocardium of the $\mathrm{E}$ group is decreased more than the control group, black arrows: apoptotic cells $(\times 400$, top: control, bottom: E group). (B) Number of the apoptotic cells measured by counting 20 areas, $25 \times 25 \mu \mathrm{m}, p<0.05$ (black bar: control, white bar: enalapril or hydralazine treated group). (C) Percentage of apoptotic myocytes and interstitial cells between control and enalapril treated group.

GAGCTCCA-3', 5'-GGCCGCGGCCACTTCTGCAGAC-3' for clusterin, and 5'-AGACAGCCAGGAGAAATCAA-3', 5'TGGGATACTGGAGATGAAGA-3' for bcl-2, all three 515, 310 , and 386 base pairs of the PCR product for each gene were obtained. The PCR was carried out in a different mode of time and temperature for each reaction period using Perkin Elmer Cetus DNA Thermal Cycler (Model 2400, Foster City, CA, U.S.A.).

For GAPDH as a house-keeping gene, PCR was performed at 30 cycles heating for $45 \mathrm{~s}$ at $94^{\circ} \mathrm{C}$ after denaturation for 5 min at $94^{\circ} \mathrm{C}$, followed by annealing for $45 \mathrm{~s}$ at $60^{\circ} \mathrm{C}$, and last a primer extension for $45 \mathrm{~s}$ at $70^{\circ} \mathrm{C}$. For bcl-2, PCR was performed at 32 cycles heating for $45 \mathrm{~s}$ at $94^{\circ} \mathrm{C}$ after denaturation for $5 \mathrm{~min}$ at $94^{\circ} \mathrm{C}$, followed by annealing for $45 \mathrm{~s}$ at $62^{\circ} \mathrm{C}$ and last a primer extension for $1 \mathrm{~min}$ at $72^{\circ} \mathrm{C}$. For clusterin, this was performed at 30 cycles heating for $30 \mathrm{~s}$ at $94^{\circ} \mathrm{C}$ after denaturation for $5 \mathrm{~min}$ at $94^{\circ} \mathrm{C}$, followed by annealing for $30 \mathrm{~s}$ at $62^{\circ} \mathrm{C}$ and primer extension for $30 \mathrm{~s}$ at $72^{\circ} \mathrm{C}$. These amplified PCR products were visible as a fluorescent band under UV rays after agarose gel electrophoresis with a difference of time and ethidium bromide staining. Polaroid photographs were scanned using Epson GT-9500 (Seiko Corp, Nagano, Japan) and quantitated by densitometer (Image PC alpha 9, N.I.H., Bethesda, U.S.A.) and the values were revised by GAPDH.

Protein extraction. Alcohol (100\%) was added to interface and organic phase remained from separation of RNA, and then the DNA portion was precipitated after being centrifuged at $5000 \mathrm{rpm}$ for $5 \mathrm{~min}$. Isopropanol was added to the remaining ethanol upper layer, which was centrifuged and dissolved in $0.3 \mathrm{M}$ guanidine hydrochloride in $95 \%$ ethanol. Afterward, this layer was washed three times and turned into a protein pellet. The extracted protein was dissolved in 1\% SDS (SDS) solution and preserved at $-20^{\circ} \mathrm{C}$. The Bradford method was used in the quantification of protein.

Immunoblot analysis. The extracted proteins were solubilized in $5 \times$ SDS loading buffer for five minutes at $95^{\circ} \mathrm{C}$ and separated by electrophoresis on 10\% SDS-polyacrylamide gels under reducing conditions. Subsequently the proteins were 
transferred to nitrocellulose membranes (Amersham Life Science, Buckinghamshire, England). The nitrocellulose membranes were blocked in 5\% skim milk with TBS-T $(0.05 \%$ Tween 20 in $50 \mathrm{mM}$ Tris, $150 \mathrm{mM} \mathrm{NaCl}, 0.05 \% \mathrm{NaN}_{3}, \mathrm{pH} 7.4$ ) at room temperature for $1 \mathrm{~h}$. The membranes were washed two times in TBS-T and incubated for $18 \mathrm{~h}$ at $4{ }^{\circ} \mathrm{C}$ with rabbit polyclonal antiserum (bcl-2: Calbiochem, Cambridge, MA, U.S.A., bcl-xl: Oncogene, Cambridge, MA, U.S.A., and clusterin: Upstate Biotechnology Incorporated, Lake Placid, NY, U.S.A.), each diluted 1:20, 1: 400 and 1:100 in TBS-T. Thereafter the membranes were washed two times with TBS-T and incubated for 40 min with an anti-rabbit IgG (Amersham Life Science, Buckinghamshire, England) at room temperature. After washing by TBS-T four times, the secondary antibody bound to the nitrocellulose was detected by incubation for 1 min with a detection reagent (Amersham Life Science, Buckinghamshire, England) and then exposed to medical x-ray film (Agfa, Mortsel, Belgium) for $1 \mathrm{~min}$. The film was developed by an using FPM-3500 Fuji x-ray Film Processor (Fuji, Otawara, Japan). After that, for stripping and reprobing, same membranes were submerged in stripping buffer ( $2 \%$ SDS in $62.5 \mathrm{mM}$ Tris-HCL, $0.1 \mathrm{M} \beta$-mercaptoethanol) and incubated at $50^{\circ} \mathrm{C}$ for $10 \mathrm{~min}$ with occasional shaking. To control equal loading, $\alpha$-tubulin (1:1000 dilution, Oncogene) and anti-mouse IgG conjugated horseradish peroxidase (1:1000 dilution, Amersham Life Science, Buckinghamshire, England) were used as primary and secondary antibodies in a same methods as above. The developed X-rays were scanned using Epson GT-9500 (Seiko Corp, Nagano, Japan) and quantitated by a densitometer (Image PC alpha 9, N.I.H., Bethesda, U.S.A.).

Statistical analysis. Data are presented as mean \pm SEM. Comparisons between the two groups were performed by the Student-Newman-Keuls methods. Statistical significance was defined as $p<0.05$.

\section{RESULTS}

Mortality rate. Six among the 25 rats of the Enalapril group (E group) (24.7\%) died. In the control group, one of the 20 rats died $(5 \%)$. The mortality rate was higher in the E group than the control group $(p<0.05)$.

Body weight and heart weight. On harvest, the average body weights were $14.6 \pm 0.5 \mathrm{~g}$ in the E group and $17.1 \pm 0.6 \mathrm{~g}$ in the control group. Weights of the hearts were $0.09 \pm 0.01 \mathrm{~g}$ in the E group and $0.11 \pm 0.00 \mathrm{~g}$ in the control group. Weights of the body and heart were reduced in the E group more than in the control group $(p<0.05)$.

Proliferating cell nuclear antigen (PCNA). In the E group, PCNA positive cells were rarely found in the myocardium of the neonatal rat heart as compared with the control group. PCNA-positive cells were $22.46 \pm 2.69$ of the control group, and $14.75 \pm 1.19$ of the E group in each field of $25 \times 25 \mu \mathrm{m}$ $(p<0.05$, Fig. 1A,B). $78.6 \pm 1.4 \%$ of PCNA-positive cells were myocytes, and $21.4 \pm 1.8 \%$ were interstitial cells in the control group, whereas $94.2 \pm 4.1 \%$ were myocytes and $5.8 \pm$ $4.1 \%$ were interstitial cells in the $\mathrm{E}$ group $(p<0.05$, Fig. $1 C)$. The reduction in proliferating myocytes in the $\mathrm{E}$ group was
$23 \%$, while the reduction in proliferating interstitial cells was $81 \%$.

Apoptosis. In the E group, apoptotic nuclei were rarely found in the myocardium as compared with the control group. Apoptotic nuclei were $2.56 \pm 00.23$ of the control group and $1.04 \pm 0.21$ of the E group in each field of $25 \times 25 \mu \mathrm{m}$, a reduction of $60 \%(p<0.05$, Fig. $2 A, B)$. In cell type identification, $94.3 \pm 1.9 \%$ of apoptotic cells were myocytes in the control group and $98.2 \pm 1.2 \%$ in the $\mathrm{E}$ group $(p>0.05$, Fig. 2C).

Expression of bcl-2 $m R N A$ and protein. As a result of semi-quantitative RT-PCR, bcl-2/GAPDH mRNA expressions were $1.02 \pm 0.02$ in the control group, and $0.99 \pm 0.01$ in the E group (Fig. $3 A, B$ ). In addition, as a result of the immunoblot analysis, bcl-2 protein density was $62.60 \pm 3.44$ units in the control group, and $68.0 \pm 5.38$ units in the E group (Fig. 4).

Expression of bcl-xl protein. As a result of immunoblot analysis, there was no significant difference between the two groups. Bcl-xl protein density was $173.25 \pm 23.94$ units in the control group, and $167.4 \pm 29.59$ units in the E group (Fig. 4).

Expression of clusterin $m R N A$ and protein. As a result of semi-quantitative RT-PCR, clusterin/GAPDH mRNA expressions were $0.90 \pm 0.01$ in the control group, and $0.92 \pm 0.02$ in the E group (Fig. $5 A, B$ ). As a result of the immunoblot analysis, however, clusterin/tubulin protein expressions were decreased significantly in the E group $(0.41 \pm 0.08)$ as compared with the control group $(0.67 \pm 0.05)$ (Fig. $6 A, B, p<$ $0.05)$.

Effect of hydralazine in newborn rats. To determine whether systemic hypotension per se alters cardiac cell prolif-

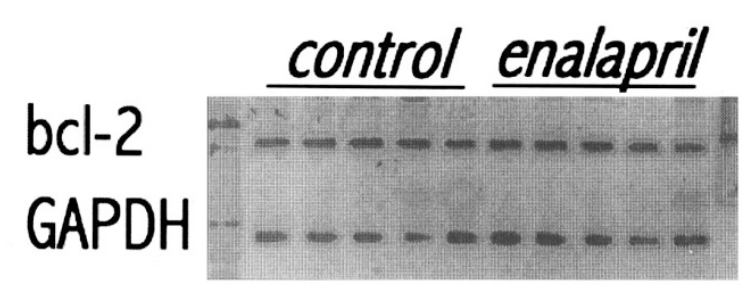

A

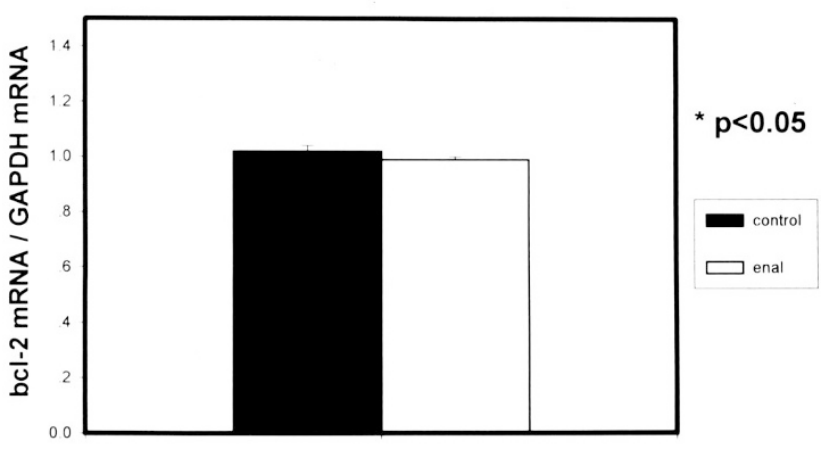

B

Figure 3. Expression of bcl-2 mRNA from the developing heart. (A) Semiquantitative rt-PCR shows that expression of bcl-2 mRNA is not different between the two groups. (B) Expression of bcl-2 mRNA between the two groups is not different (black bar: control, white bar: enalapril treated group). 


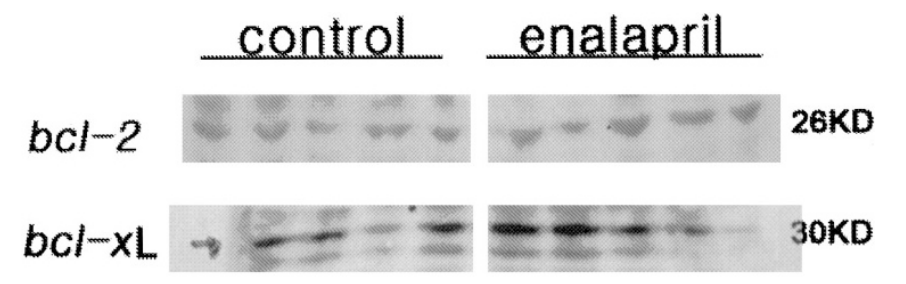

$\mathrm{Bcl}-2$ and $\mathrm{bcl}-\mathrm{x}$ protein expression

Figure 4. Expression of the bcl-2 and bcl-xl proteins from the developing heart in both group. Western blot assay of the bcl-2 and bcl-xl proteins show that there is no difference between the two groups (Top: bcl-2, bottom:bcl-xl).

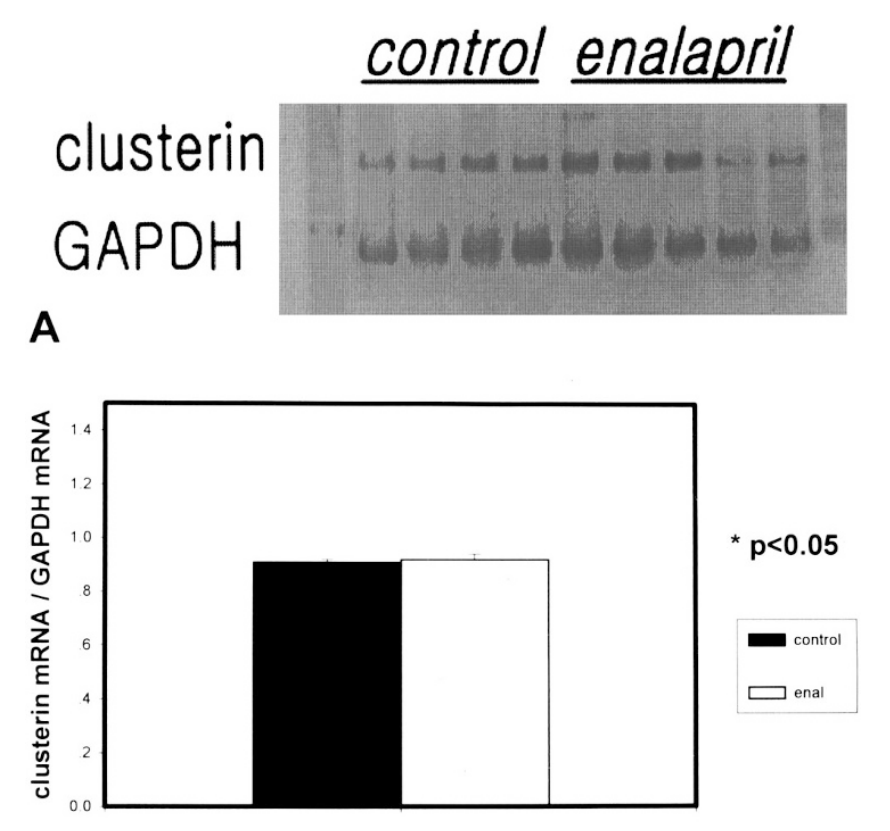

B

Figure 5. Expression of clusterin mRNA from the developing heart $(A)$ Semiquantitative rt-PCR shows that expression of clusterin mRNA is not different between the two groups. $(B)$ Expression of clusterin mRNA between the two groups is not different (black bar: control, white bar: enalapril treated group).

eration and apoptosis, newborn rats were given hydralazine. Hydralazine did not alter cardiac cell proliferation and apoptosis. Hydralazine treated hearts had $23.4 \pm 2.4$ PCNA positive cells and $1.65 \pm 0.13$ apoptotic cells, and control hearts had $21.4 \pm 1.5$ PCNA positive cells and $1.62 \pm 0.08$ apoptotic cells (Fig. 1B, Fig. 2B).

\section{DISCUSSION}

A major finding in the present study is the demonstration that chronic ACE inhibition impairs normal postnatal cardiac growth. Development and growth of the heart is controlled by a variety of intrinsic and extrinsic factors. The developing blood volume and pressure in the neonatal heart dictate the hypertrophic stage of normal growth and this may be further modified by abnormal hemodynamic and humoral factors within the myocardium (20). The myocardium is composed of cardiac myocytes and interstitial cells (vascular endothelial

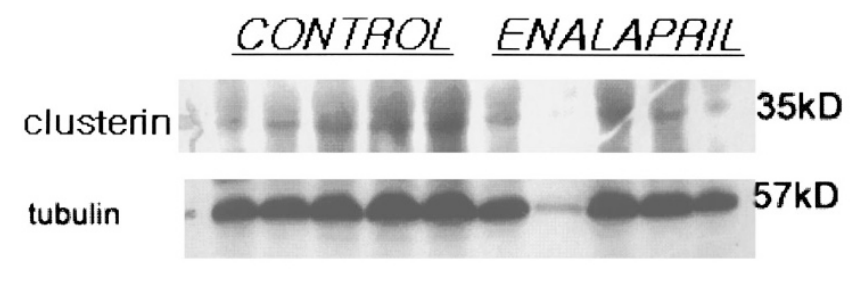

Clusterin protein expression by Western blotting

A

(heart)

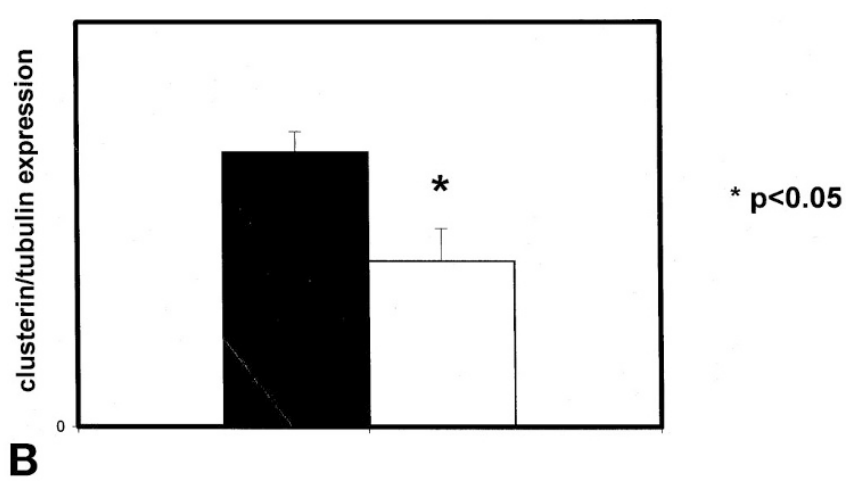

Figure 6. Clusterin protein expression of the developing heart. $(A)$ Western blot assay of the clusterin protein shows that expression of clusterin in the $\mathrm{E}$ group is significantly more decreased than the control group (tubulin - a loading control). (B) clusterin/tubulin protein expressions measured by densitometer, black bar: control, white bar: enalapril treated group, $p<0.05$.

cells, vascular smooth muscle cells, fibroblasts, and macrophages). Cardiac myocytes, which form the major functional and structural portion of the heart, can divide only in the fetal and neonatal periods, after which these cells undergo hypertrophy. Cardiac pressure load, in particular during cardiac growth and development, has been identified as an important mechanism regulating the growth of the heart in vivo (21). The RAS is involved in the regulation of cardiac growth through this load dependent pathway. ANG-II, as the main effector peptide in the RAS, elicits potent vasoconstriction, causes inotropic and chronotropic changes in the heart, and increases growth of cardiac and vascular smooth muscle cells mainly via AT1 receptors $(4,22-24)$. In addition, it has a stimulatory effect on protein synthesis and on cellular hypertrophy of the heart inducing growth-promoting genes in cardiac myocytes.

Studies in newborn animals and human infants have shown that the activity of the RAS increases at birth compared with that in the adult $(1,3)$. This increased activity has previously been shown to be important in regulating several of the cardiovascular and autonomic adaptations which occur during the transition from fetal to newborn life $(1,25)$. More evidence that the RAS may be involved in the regulation of cardiac growth comes from pharmacological studies using inhibitors of the system by blocking the effects of ACE and the ANG-II AT1 receptor. Beinlich et al., $(26,27)$ found that ANG-II is required for the normal neonatal cardiac development of pigs.

During early development, rat cardiac muscle cells actively proliferate. Shortly after birth, division of cardiac muscle cells ceases, whereas DNA synthesis continues for approximately two weeks at a progressively diminishing rate (28). During the 
postnatal period, there is an uncoupling of DNA replication from cell division and rapid polyploidization occurs during the first postnatal week $(29,30)$. In this study, ACE inhibition diminished the number of proliferating myocytes by $23 \%$, and of interstitial cells by $81 \%$. The reduction in myocyte proliferation by ACE inhibition presumably contributed to the reduction in cardiac mass. It has been shown that blocking ANG-II by either ACE inhibition or AT1 receptor inhibition results in a significant reduction of macrophage and interstitial cell infiltration and proliferation in the adult rat kidney (31, 32). However, there are no reports regarding the relationship between ANG-II and interstitial cells in the developing heart. The precise action of ANG-II on interstitial cell proliferation and regulation on cardiac development needs to be further clarified.

In this study, cardiac apoptosis occurred primarily in myocytes and was decreased $60 \%$ by ACE inhibition, but the prevalence of apoptotic cells was approximately 10-fold less than that of proliferating cells. This presumably accounts for the loss in cardiac mass in Enalapril treated rats despite a reduction in apoptosis. Apoptosis is a ubiquitous mode of physiologic cell death, and is also a major factor in the control of organ remodeling during normal and abnormal growth (33, 34). Apoptosis in the heart is only now being recognized (35, 36). The heart undergoes extensive remodeling during embryogenesis, wherein apoptosis significantly contributes to the development of the cardiac chambers and correct routing of the great vessels. Apoptotic myocyte cell death occurs in the early stages of postnatal development in the rat heart, becoming undetectable by $21 \mathrm{~d}$ after birth (12). Recently, ANG-II was shown to induce apoptosis in myocytes via the activation of surface AT-1 receptors, resulting in an increase in cytosolic calcium and the stimulation of calcium dependent dNASE-1 (37, 38). Angiotensin II stimulated a 2.5 -fold increase in apoptosis in neonatal ventricular myocytes (38).

In the present study, both apoptosis and cellular proliferation in the developing rat heart were decreased in the Enalapril treated group. Although blood pressure was not monitored directly in this study, hydralazine treatment was used to control for the effects of hypotension in the observed cellular responses in the developing rat heart. The results that unlike Enalapril, hydralazine did not alter cell proliferation or apoptosis. Our data are in agreement with previous reports in ten to eleven week old rats treated with Enalapril, hydralazine, or calcium channel blockers, showing that the effect of ACE inhibition on growth is not due to changes in blood pressure (39). Hence, these findings suggest that the cellular actions of ANG-II in the developing heart are independent of hemodynamic changes. It may be speculated that this apoptotic activity is mediated by several apoptosis related growth factors and cytokines (40). Bcl-2 proto-oncogene product, which is a protein mainly present in mitochondrial membranes and nuclear envelopes, has been shown to be inversely related to apoptotic cell death in several model systems (12). Apoptosis repressing ability of bcl-2 and bcl-x protein have been related to the neutralizing activity of pro apoptotic effect through the BAX protein which promotes apoptosis as another bcl-2 family member $(41,42)$. Kajstura et al. (12) had found that cardiac myocyte apoptotic activity in early development increased at 1, 5, and $11 \mathrm{~d}$ postnatally, and was no longer detectible at $21 \mathrm{~d}$. They also noted that bcl-2 mRNA levels were high in fetal myocytes, decreased markedly at 1 to $5 \mathrm{~d}$, and progressively increased at 11-21 d. The chronic administration of losartan (an AT1 receptor blocker) is associated with normalization of cardiac apoptosis, BAX protein, and the bcl-2/BAX ratio in treated spontaneously hypertensive rats (but with no significant change in the expression of bcl-2) (43). In our study, no significant changes in the expression of bcl-2 or bcl-x 1 were observed in the developing heart after Enalapril administration. However, apoptotic members of the bcl-2 family can interact, and the overall effect on cell survival depends on the balance between the activity of apoptotic and anti-apoptotic proteins (44).

Clusterin is a glycoprotein produced in response to tissue injury, and it also protects cell membranes and promotes cell aggregation (45). Clusterin is induced in some models of apoptosis and is one of the proteins likely to be involved in the maintenance of cell integrity. While there is no expression of clusterin in cells undergoing apoptosis, clusterin is expressed by surrounding surviving cells during in vitro programmed cell death (46). In the present study, although there was no significant effect of Enalapril on cardiac expression of clusterin mRNA, Enalapril decreased clusterin protein in the neonatal rat heart. While not consistent with an anti-apoptotic role for clusterin in this setting, these results suggest that ANG-II modulates clusterin expression in the heart as has been demonstrated in the kidney (47).

In the kidney, the effects of ANG-II on clusterin expression are dependent on the predominant ANG-II receptor type (47). At least two ANG-II receptors subtypes, the AT1 and AT2 receptors, have been identified. In developing rats, both in situ hybridization and autoradiographic studies have shown that the AT2 receptor expression is high in the developing embryo, is localized to fetal mesenchymal tissues, and decreases late in development and with postnatal maturation (26, 48-52). The predominance of AT2 receptors during fetal life as led investigators to postulate that these receptors may be involved in protein synthesis and growth $(48,53)$. ANG-II mediated cell proliferation and maturation of tissue via the AT2 receptor is important in the developing organ. Further studies are needed to clarify the downstream signaling mechanisms responsible for ANG-II modulation of apoptosis in the developing rat heart.

\section{CONCLUSION}

In summary, inhibition of endogenous ANG-II in the neonatal rat decreased myocyte proliferation, which may account at least in part for impaired cardiac growth. In addition, ACE inhibition had an even more profound effect to reduce cardiac interstitial cell proliferation. These effects of ACE inhibition were counterbalanced by a reduction in myocyte apoptosis, which, however, accounted for only $10 \%$ of the relative fraction of cells undergoing proliferation. The overall effect of ACE inhibition on myocyte turnover was therefore a net reduction in cellular proliferation. Although ACE inhibition reduced the abundance of clusterin in the neonatal rat heart, 
steady state gene expression was not affected. Additional studies will be required to elucidate the cellular mechanisms responsible for disruption of cellular proliferation and apoptosis by ACE inhibition in the developing heart. We speculate that a reduction in the number of myocytes may lead to maladaptive hypertrophy of remaining myocytes, and may contribute to cardiac damage later in life.

\section{REFERENCES}

1. Davidson D 1987 Circulating vasoactive substance and hemodynamic adjustments at birth in lambs. J Appl Physiol 63:676-684

2. Jones CT, Ritchie K 1978 The metabolic and endocrine effects of circulating catecholamines in fetal sheep. J Physiol Lond 285:381-393

3. Guillery EN, Robillard JE 1993 The renin-angiotensin system and blood pressure regulation during infancy and childhood. In: Rocchini AP (ed) The Pediatric Clinics of North America: Childhood Hypertension. WB Saunders, Philadelphia, pp 61-77

4. Baker KM, Aceto JF 1990 Angiotensin II stimulation of protein synthesis and cell growth in chick heart cells. Am J Physiol 259:H610-H618

5. Black MJ, Bertram JF, Campbell JH, Campbell GR 1995 Angiotensin II induces cardiovascular hypertrophy in perindopril-treated rats. J Hypertens 13:683-692

6. Scherman RN, Langley-Evans SC 1998 Early administration of angiotensinconverting enzyme inhibitor captopril prevents the development of hypertension programmed by intrauterine exposure to a maternal low-protein diet in the rat. Clin Sci(colch) 94:373-381

7. Grinstead WC, Young JB 1992 The myocardial renin-angiotensin system: existence, importance, and clinical implication. Am Heart J 123:1039-1045

8. Dostal DE, Baker KM 1993 Evidence of a role of an intracardiac renin-angiotensin system in normal and failing hearts. Trends Cardiovasc Med 3:67-34

9. Parratt JR 1994 Cardioprotection by angiotensin converting enzyme inhibitors-the experimental evidence. Cardiovasc Res 28:183-189

10. Vaughan DE, Pfeffer MA 1994 Angiotensin converting enzyme inhibitors and cardiovascular remodelling. Cardiovasc Res 28:159-165

11. Yoo KH, Cheon HW, Choi BM, Hong YS, Lee JW, Kim SK 1998 Angiotensin converting enzyme inhibition increases apoptosis and bcl-2 expression in the neonatal rat kidney. J Am Soc Nephrol 9:A2613

12. Kajstura J, Mansukhani M, Cheng W, Reiss K, Krajewski S, Reed JC, Quaini F, Sonnenblick EH, Anversa P 1995 Programmed cell death and expression of the protooncogene bcl-2 in myocytes during postnatal maturation of the heart. Exp Cell Res 219:110-121

13. Blaschuk O, Burdzy K, Fritz IB 1983 Purification and characterization of a cellaggregating factor(clusterin), the major glycoprotein in raw rete testis fluid. J Biol Chem 12:7714-7720

14. Tenniswood MP, Guenette RS, Lakins J, Mooibroek M, Wong P, Welsh J-E 1992 Active cell death in hormone-dependent tissues. Cancer Metas Rev 11:197-220

15. Fritz IB 1992 What is clusterin? Clin Exp Immunol 88:375

16. Gomez RA, Lynch KR, Chevalier RL, Everett AD, Johns DW, Wilfong N, Peach MJ, Carey RM 1988 Renin and angiotensinogen gene expression and intrarenal renin distribution during ACE inhibition. Am J Physiol 254:F900-F906

17. Tufro-McReddie A, Romano LM, Harris JM, Ferder L, Gomez RA 1995 Angiotensin II regulates nephrogenesis and renal vascular development. Am J Physiol 269:F110F115

18. Greeberg S 1980 Studies on the effect of chronic oral administration of minoxidil and hydralazine on vascular function in spontaneously hypertensive rats. J Pharmacol Exp Ther 215:279-286

19. Ishii H, Itoh K, Nose T 1980 Different antihypertensive effects of nifedipine in conscious experimental hypertensive and normotensive rats Eur J Pharmacol 64:21-29

20. Weber KT, Brilla CG, Janicki JS 1991 Signals for the remodelling of the cardiac interstitium in systemic hypertension. J Cardiovasc Pharmacol 17(suppl):S14-S19

21. Chien KR, Knowlton KV, Zhu H, Chien S 1991 Regulation of cardiac gene expression during myocardial growth and hypertrophy: molecular studies of an adaptive physiological response. FASEB J 5:3037-3046

22. Baker KM, Booz GW, Dostal DE 1992 Cardiac actions of angiotensin II: role of an intracardiac renin- angiotensin system. Annu Rev Physiol 54:227-241

23. Geisterfer AAT, Peach MJ, Owens GK 1988 Angiotensin II induces hypertrophy, not hyperplasia, of cultured rat aortic smooth muscles cells. Circ Res 62:749-756
24. Berk BC, Vekshtein V, Gorden HM, Tsuda T 1989 Angiotensin II-stimulated protein synthesis in cultured vascular smooth muscle cells. Hypertension 13:305-314

25. Segar JL, Mazursky JE, Robillard JE 1994 Changes in ovine renal sympathetic nerve activity and baroreflex function at birth. Am J Physiol 267:H1824-H1832

26. Beinlich CJ, White GJ, Baker KM, Morgan HE 1991 Angiotensin II and left ventricular growth in newborn pig heart. J Mol Cell Cardiol 23:1031-1038

27. Beinlich CJ, Rissinger CJ, Morgan HE 1995 Mechanism of rapid growth in the neonatal pig heart. J Mol Cell Cardiol 27(1):273-281

28. Peterson RO, Baserga R 1965 Nucleic acid and protein synthesis in cardiac muscle of growing and adult mice. Exp Cell Res 40:340-352

29. Rumayantsev PP 1977 Interrelations of the proliferation and differentiation processes during cardiac myogenesis and regeneration. Int Rev Cytol 51:187-273

30. Clubb FJ Jr, Bishop SP 1984 Formation of binucleated myocardial cells in the neonatal rat. Lab Invest 50:571-577

31. Wu LL, Yang N, Roe CJ, Cooper ME, Gilbert RE, Atkins RC, Lan HY 1997 Macrophage and myofibroblast proliferation in remnant kidney: role of angiotensin II. Kidney Int 52:S221-S225

32. Ishidoya S, Morrissey J, McCracken R, Reyes A, Klahr S 1995 Angiotensin II receptor antagonist ameliorates renal tubulointerstitial fibrosis caused by unilateral ureteral obstruction. Kidney Int 47:1285-1294

33. Walker NL, Harmon BV, Gobe GC, Kerr JFR 1988 Patterns of cell death. Methods Achiev Exp Pathol 13:18-54

34. Wyllie NI, Kerr JFR, Currie AR 1980 Cell death: the significance of apoptosis. Int Rev Cytol 68:251-306

35. Hamet P 1995 Proliferation and apoptosis in hypertension. Curr Opin Nephrol Hypertens 4:1-7

36. Hamet P, Richard L, Dam TV, Teiger E, Orlov SM, Gaboury L, Gossard F, Tremblay J 1995 Apoptosis in target organs of hypertension. Hypertension 26:642-648

37. Kajstura J, Cigola E, Malhotra A, Li P, Cheng W, Meggs LG, Anversa P 1997 Angiotensin II induces apoptosis of adult ventricular myocytes in vitro. Mol Cell Cardiol 29:859-870

38. Cigola E, Kajstura J, Li B, Meggs LG, Anversa P 1997 Angiotensin II activates programmed myocyte cell death in vitro. Exp Cell Res 231:363-371

39. Fogo A, Yoshida Y, Yared A, Ichikawa I 1990 Importance of angiogenic action of angiotensin II in the glomerular growth of maturing kidneys. Kidney Int 38:10681074

40. Griffin SA, Brown CW, MacPherson F, McGrath JC, Wilson VG, Korsgaard N, Mulvany MJ, Lever AF 1991 Angiotensin II caused vascular hypertrophy in part by a non-pressor mechanism. Hypertension 17:626-635

41. Umansky SR, Tomei LD 1997 Apoptosis in the heart. Adv Pharmacol 41:383-407

42. Azhar G, Liu L, Zhang X, Wei JY 1999 Influence of age on hypoxia/reoxygenationinduced DNA fragmentation and bcl-2, bcl-E1, bax and fas in the rat heart and brain Mech Ageing Dev 112:5-25

43. Frtuno MA, Rovassa S, Etayo JC, Diez J 1998 Overexpression of Baxc protein and enhanced apoptosis in the left ventricle of spontaneouly hypertensive rats: effect of AT 1 blockade with losartan. Hypertension 32:280-286

44. Adams JM, Cory S 1998 The Bcl-2 protein family: arbiters family: arbiters of cell survival. Science 281:1305-1308

45. Rosenberg ME, Silkensen J 1995 Clusterin: physiologic and pathophysiologic consideration. Int J Biochem Cell Biol 27:633-645

46. French LE, Wohlwend A, Sappino AP, Tschopp J, Schifferli JA 1994 Human clusterin gene expression is confined to surviving cells during in vitro programmed cell death. J Clin Invest 93:877-884

47. Yoo KH, Thornhill BA, Chevalier RL 2000 Angiotensin stimulates TGF-beta 1 and clusterin in the hydronephrotic neonatal rat kidney Am J Phsiol 278:R640-R645

48. Grady EF, Sechi LA, Griffin CA, Schambelan M, Kalinyak JE 1991 Expression of AT2 receptors in the developing rat fetus. J Clin Invest 88:921-933

49. Aceto JF, Baker KM 1990 [Sar ${ }^{1}$ ] angiotensin II receptor-mediated stimulation of protein synthesis in chick heart cells. Am J Physiol 258:H806-H813

50. Sadoshima JI, Izumo S 1993 Molecular characterization of angiotensin II-induced hypertrophy of cardiac myocytes and hyperplasia of cardiac fibroblasts. Circ Res 73:413-423

51. Smith RD, Chiu AT, Wong PC, Herblin WF, Timmermans PBMWM 1992 Pharmacology of nonpeptide angiotensin II receptor antagonist. Annu Rev Pharmacol Toxicol 32:135-165

52. Chiu AT, Herblin WF, Ardecky RJ, McCall DE, Carini DJ, Dunica JV, Pease LJ, Wexler RR, Wong PC, Johnson AL, Timmermans PBMWM 1989 Identification of angiotensin II receptor subtypes. Biochem Biophys Res Commun 165:196-203

53. Shanmugam S, Corvol P, Gasc JM 1996 Angiotensin II type 2 receptor mRNA expression in the developing cardiopulmonary system of the rat. Hypertension 28:91-97 